\title{
PENGEMBANGAN BUDIDAYA JAMUR TIRAM DI LINGKUNGAN KAMPUS FMIPA UNIMED
}

\author{
Martina Restuati' ${ }^{1)}$, Ahmad Shafwan S. Pulungan²), Ricky Andi Syahputra ${ }^{3)}$, Ani Sutiani ${ }^{4)}$, \\ Pasar Maulim Silitonga ${ }^{5)}$, Nanda Pratiwi'), Rahmad Gultom ${ }^{7}$ \\ Universitas Negeri Medan ${ }^{1,2,3,4,5,6,7)}$ \\ *Penulis Korespodensi : t.restuati@gmail.com
}

\begin{abstract}
ABSTRAK
Universitas Negeri Medan sebagai kampus yang memiliki Jurusan Biologi yang mempelajarai berbagai jamur dan pekembangannya dalam matakuliah mikrobiologi serta didukung oleh lahan yang mendukung untuk melakukan pengembangan jamur. Mengingat cukup potensi budidaya jamur tiram di Unimed khususnya FMIPA diperlukan suatu upaya untuk meningkatkan pengetahuan mahasiswa dan masyarakat sekitar. Upaya yang dilakukan adalah memberikan pelatihan bagaimana cara pengembangan tanaman jamur tiram melalui lima tahapan, yaitu : (1) pemamparan materi tentang pengemasan jamur tiram, (2) perizinan usaha jamur tiram, (3) sertifikasi halal produk jamur tiram, (4) Pendampingan perizinan dan sertifikasi halal, (5) review terhadap pelatihan yang telah dilaksanakan serta menarik kesimpulan. Dengan diberikannya pengetahuan dan pemahaman dalam melakukan pengembangan budidaya tanaman jamur tiram akan menjadi bekal bagi para mahasiswa untuk pengembangan yang lebih maksimal sehingga dapat dipasarkan ke supermarket dan memberikan income generate bagi FMIPA Unimed khususnya Jurusan Biologi. Dengan diberikannya pengetahuan dan pemahaman dalam melakukan budidaya tanaman jamur tiram akan menjadi bekal bagi para mahasiswa untuk pengembangan yang lebih maksimal dan pemberian pelatihan budidaya jamur tiram dan dihasilkan akan memiliki nilai ekonomis cukup tinggi. Kegiatan ini dapat membantu mahasiswa sebagai bekal untuk berwirausaha dan sebagai sarana pembelajaran. Selain itu kegiatan ini akan membantu untuk mewujudkan impian FMIPA Unimed menjadikan menjadi kampus penghasil jamur tiram.
\end{abstract}

Kata Kunci: budidaya Jamur tiram, Gizi, FMIPA, UNIMED.

\begin{abstract}
Universitas Negeri Medan is a campus that has a Biology Department that studies various fungi and their development in microbiology courses and is supported by supporting land to develop oyster mushrooms. Given the sufficient potential of oyster mushroom cultivation in Unimed, especially FMIPA, an effort is needed to increase the knowledge of students and the surrounding community. Efforts are being made to provide training on how to develop oyster mushroom plants through five stages, namely: (1) presentation of material on oyster mushroom packaging, (2) oyster mushroom business licensing, (3) halal certification of oyster mushroom products, (4) licensing assistance and halal certification, (5) review of the training that has been carried out and draw conclusions. Given the knowledge and understanding in developing oyster mushroom cultivation, it will be a provision for students to develop more optimally so that it can be marketed to supermarkets and provide income generation for FMIPA Unimed, especially the Department of Biology. With the provision of knowledge and understanding in cultivating oyster mushroom plants, it will be a provision for students to develop more optimally and provide training in oyster mushroom cultivation and the results will have quite high economic value. This activity can help students as provisions for entrepreneurship and as a means of learning. In addition, this activity will help to realize the dream of FMIPA Unimed to become a campus for producing oyster mushrooms.
\end{abstract}

Keywords: oyster mushroom cultivation, nutrition, FMIPA, UNIMED.

\section{PENDAHULUAN}

Berangkat dari niat untuk mendalami ilmu pengetahuan yang terbuka lebar serta keinginan untuk memberikan manfaat yang lebih besar bagi masyarakat maka dengan segenap pengalaman, pengetahuan, dan berbagai hasil survey serta konsultasi, peneliti 
membuat pengembangan budidaya jamur tiram ini. Upaya pengembangan berbagai pembelajaran guna memberikan perbaikan pembelajaran juga banyak dilakukan oleh para ahli. Bentuk pengembangan pembelajaran berupa pengembangan model, metode, hingga media pembelajaran. Seluruhnya dilakukan guna meningkatkan pemahaman mahasiswa terhadap materi pembelajaran. Tidak hanya kemampuan pada ranah pengetahuan namun pengembangan pembelajaran pada aspek psikomotor dan afektif juga harus muncul pada setiap kegiatan pembelajaran. Untuk mewujudkan hal tersebut di dalam pembelajaran diperlukan adanya inovasi dalam kegiatan pembelajaran. Tuntutan kurikulum Kerangka Kualifikasi Nasional Indonesia (KKNI) yang ada saat ini berada pada tahapan capaian pembelajaran yang menghasilkan manusia yang memiliki kompetensi sesuai dengan tingkatan pendidikannya. Dalam rangka menghasilkan output tersebut, proses menjadi sangat penting. Bukan hanya mahasiswa yang menjadi andil dalam mencapai tujuan terebut, namun dosen juga memegang peranan yang sangat penting. Dosen dituntut harus mampu menyelenggarakan kegiatan pembelajaran yang sesuai dengan capaian kurikulum.

Universitas Negeri Medan sebagai salah satu Universitas penyelenggara program studi pendidikan biologi di Indonesia telah melaksanakan kurikulum KKNI. Ketercapaian hasil pembelajaran jenjang sarjana pada level 6 bukan hanya berimplikasi pada pemahaman Lembaga pendidikan harus mengembangkan IPTEKS pada mahasiswa karena hal tersebut merupakan capaian pembelajaran KKNI pada level 6, yaitu mahasiswa dituntut agar mampu mengaplikasikan bidang keahliannya dan memanfaatkan IPTEKS pada bidangnya dalam penyelesaian masalah serta mampu beradaptasi terhadap situasi yang dihadapi (Kementrian Pendidikan dan Kebudayaan, 2011).

Fenomena perkembangan dan kemajuan IPTEK, khususnya bidang Biologi, dan perkembangan sistem informasi yang semakin canggih merupakan dua hal yang harus diantisipasi oleh lembaga pendidikan formal, terutama perguruan tinggi agar dapat memberikan informasi dan perkembangan yang aktual terhadap peserta didik (Safitri et al., 2014). 
Setiap perkembangan IPTEKS tersebut akan berimbas pada komponen isi matakuliah dan bahan ajar yang terkait (Mbulu \& Suhartono, 2004). Jenis matakuliah dalam bidang Biologi yang terkena dampak dari perkembangan IPTEKS biasanya adalah yang berhubungan dengan alat-alat laboratorium, perkembangan teknologi dan analisis molekular terkini, seperti Mikorbiologi, Genetika, Fisiologi, Evolusi, Biologi Sel, dan Taksonomi. Salah satu matakuliah harus mengikuti perkembangan IPTEKS di Universitas Negeri Medan adalah Mikrobiologi.

$$
\text { Pelaksanaan perkuliahan }
$$

berbasis kurikulum KKNI mengacu pada profil lulusan, capaian pembelajaran dan bahan kajian pada setiap matakuliah. Perkuliahan berlangsung dengan menerapkan 6 (enam) tugas yang terdiri dari tugas rutin, mini riset, critical book review, review journal, proyek, rekayasa ide sesuai SK Rektor nomor 065/UN33/kep/2016. Perkuliahan yang dilaksanakan pada matakuliah Mikrobiologi juga sudah mengacu kepada pembelajaran yang berpusat kepada mahasiswa (Student centered Learning,SCL), dimana mahasiswa senantiasa dilibatkan dalam memperoleh dan mengolah informasi terutama dalam mempresentasikan materi perkuliahan. Dosen pengampu matakuliah berupa yang menggunakan berbagai pendekatan, strategi dan model pembelajaran yang berpusat pada mahasiswa agar mahasiswa dapat mencapai tujuan pembelajaran seperti yang sudah dijabarkan dari kompetensikompetensi dasar sesuai silabus.

Matakuliah

Mikrobiologi merupakan matakuliah yang mempelajari tentang mikroorganisme seperti bakteria, ragi, dan fungi untukberbagai keperluan seperti wine, pengembangan adonan dan penemuan antibiotika. Pada zaman yang semakin maju ini, kita dituntut untuk dapat menyelesaikan berbagai masalah dengan seefisien mungkin. Dengan mendirikan suatu usaha, dapat dijadikan jalan keluar untuk menyelesaikan masalah ekonomi yang terjadi di masyarakat. Misalnya, budidaya jamur tiram merupakan salah satu usaha yang dapat dijadikan solusi untuk mengurangi permasalahan yang ada. Usaha jamur tiram, dalam hal ini jamur tiram dijadikan suatu usaha dalam skala rumah tangga.

Masyarakat Indonesia dituntut untuk semakin bersaing pada dimensi 
ekonomi yang lebih dinamis, tidak hanya bersaing secara lokal, namun juga secara global. Potensi masyarakat dan kekayaan Indonesia sangat beraneka ragam, namun belum dapat berfungsi secara maksimal. Banyaknya pengangguran dapat memicu masalah ekonomi. Salah satu contoh potensi alam Indonesia adalah jamur tiram.

Jamur tiram merupakan salah satu bahan makanan yang sedang naik daun. Kandungan gizinya yang tinggi, serta manfaat jamur tiram yang sangat baik untuk kesehatan menjadikannya sebagai bahan pangan yang mulai banyak diburu masyarakat. Selain kandungan dan manfaat yang begitu banyak bagi kesehatan, jamur tiram juga merupakan salah satu komoditas pertanian yang dalam proses produksi tidak menggunakan pupuk kimia sintetis, sehingga komoditas ini tergolong bebas dari serapan bahan kimia sintetis. Proses produksi jamur tiram juga tidak terlalu banyak terkontaminasi oleh paparan pestisida, karena memang penanggulangan hama dan penyakitnya sangat sedikit melibatkan pestisida, bahkan banyak diantara pembudidaya jamur tiram yang tidak melibatkan pestisida untuk menangani serangan hama penyakit.
Budidaya jamur tiram mampu mendatangkan keuntungan yang sangat menggiurkan baik dilakukan dalam skala kecil maupun besar. Hal ini tidak lepas dari tingginya permintaan dan nilai jual dari jamur tiram. Kegiatan budidaya jamur tiram di Indonesia, masih tergolong rendah jika dibandingkan dengan kebutuhan atau permintaan dari konsumen tiap harinya. Hal ini dapat dilihat dari kenaikan permintaan jamur tiram yang setiap tahunnya mengalami peningkatan. Berdasarkan penelitian yang dilakukan pakar jamur di Departemen Sains Kementrian Industri Thailand bebarapa zat yang terkandung dalam jamur tiram atau Oyster mushroom adalah protein (10,5-30,4\%); karbohidrat 50,59 \%; serat $1,56 \%$; lemak $0,17 \%$ dan abu $1,14 \%$. Selain kandungan ini, Setiap 100 gram jamur tiram segar ternyata juga mengandung 45,65 kalori; 8,9 mg kalsium: 1,9 mg besi; 17,0 $\mathrm{mg}$ fosfor. 0,15 mg Vitamin B1; 0,75 mg vitamin B2 dan 12,40 mg vitamin C. ( Suharjo, 2007)((Nasution 2016).

Jamur tiram merupakan salah satu jenis jamur yang banyak diminati oleh masyarakat Indonesia dan semua kalangan menyukainya. Selain karena minat masyarakat yang tinggi, 
pemeliharaan untuk usaha jamur tiram juga mudah dan dapat dijadikan usaha sampingan untuk menambah pemasukan. Hanya saja, dibutuhkan kebersihan, ketelitian dan ketekunan yang tinggi. Usaha ini dapat dijalankan secara individu dan kelompok. Dengan adanya pengabdian ini diharapkan kita dapat mengetahui kandungan gizi yang terkandung dalam jamur tiram, Mengetahui cara menanam jamur tiram yang benar, Mengetahui masa panen dan cara memanen jamur tiram yang benar, Mengetahui apa saja yang harus diperhatikan untuk mengurangu kegagalan dalam pembudidayaan jamur tiram, Mengetahui cara pengendalian jamur yang terkena hama atau penyakit.

\section{METODE PELAKSANAAN}

Kegiatan ini dilakukan dengan pendekatan sosialisasi dan metode pelatihan. Rencana kegiatan ini meliputi beberapa tahapan-tahapan yang dilakukan dengan melihat permasalahan yang ada dimana pemanfaatan lahan di FMIPA unimed. Upaya yang dilakukan adalah memberikan pelatihan bagaimana cara pengembangan tanaman jamur tiram melalui lima tahapan, yaitu : (1) pemamparan materi tentang pengemasan jamur tiram, (2) perizinan usaha jamur tiram, (3) sertifikasi halal produk jamur tiram, (4) Pendampingan perizinan dan sertifikasi halal, (5) review terhadap pelatihan yang telah dilaksanakan serta menarik kesimpulan. Dengan diberikannya pengetahuan dan pemahaman dalam melakukan pengembangan budidaya tanaman jamur tiram akan menjadi bekal bagi para mahasiswa untuk pengembangan yang lebih maksimal sehingga dapat dipasarkan ke supermarket dan memberikan income generate bagi FMIPA Unimed khususnya Jurusan Biologi. Dengan diberikannya pengetahuan dan pemahaman dalam melakukan pengembangan budidaya tanaman jamur tiram menjadi bekal bagi para mahasiswa dan dosen untuk mengembangkan rumah jamur tiram yang lebih maksimal.

\section{HASIL DAN PEMBAHASAAN}

Kegiatan pengembangan budidaya jamur tiram ini sebagai suatu kegiatan untuk meningkatkan pemahaman mahasiswa dan masyarakat terhadap budidaya jamur sekaligus sebagai pemahaman usaha jamur. Kegiatan ini dimaskudkan untuk memberikan informasi dan penjelasan kepada masyarakat mengenai peningkatan pengetahuan masyarakat tentang Budidaya Jamur Tiram. 
Kegiatan budidaya jamur tiram sebagai upaya pemanfaatan lahan kampus agar produktif dimulai dengan merancang tempat dan lokasi pembuatan tempat pondok jamur (kumbum). Hasil kegiatan budidaya jamur tiram menunjukkan bahwa kegiatan ini berdampak positif dalam peningkatan pemanfaatan lahan kampus sebagai tempat budidaya jamur tiram. Hal ini ditunjukkan dengan termanfaatkan lahan yang berlokasi di belakang Laboratorium Biologi yang sebelumnya berupa lahan kosong yang terdapat berbagai tanaman dan semak. Lahan tersebut dijadikan sebagai tempat pembuatan pondok jamur (kumbum). Lahan yang dipakai sebagai kumbum (rumah) jamur berukuran $5 \times 10 \mathrm{~m}$ yang berlokasi di belakang laboratorium biologi yang selama ini tempat tersebut tidak terpakai (Gambar 1).

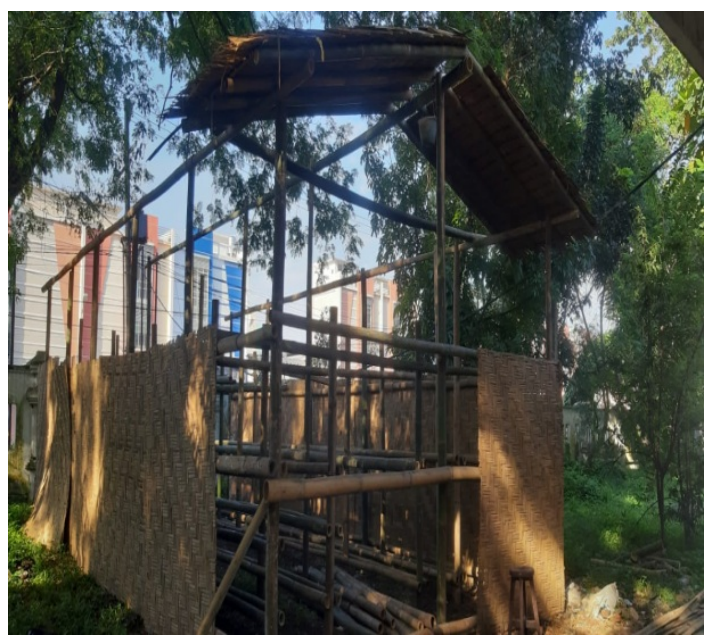

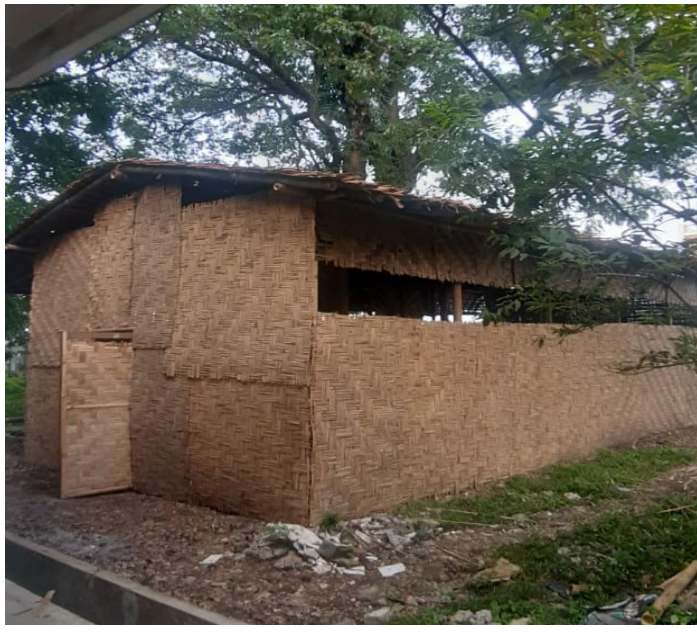

Gambar 1. Pondok jamur

Pondok jamur yang telah berdiri dengan baik dengan komposisi bambu sebagai tiang dan penyangga rak jamur dan dinding terbuat dari anyaman bambu serta atap terbuat dari nipah. Pada pondok jamur tersebut diletakkan 5000 buah baglog yang berisi bibit jamur (Gambar 2). Baglog berisi campuran antara serbuk kayu, dedak dan bibit jamur. Setiap baglog mampu menghasilkan jamur tiram dengan ukuran yang bervariasi. Periode pemanenan jamur tergantung dengan kondisi lingkungan dan kemampuan miselia jamur berkembang. Kondisi pemanenan dilakukan pada pagi hari dan atau sore hari tergantung kondisi jamur, karena jamur tiram membutuhkan udara yang lembab ((Abdullah, Hardhienata, and Chairunnas 2012). Ada dua kegiatan 
utama dalam budidaya jamur tiram.

Tahap pertama adalah membuat media tanam dan menginokulasikan bibit jamur ke dalam media tanam tersebut. Sehingga media ditumbuhi miselium berwarna putih seperti kapas. Tahap kedua adalah menumbuhkan miselium tersebut menjadi badan buah.
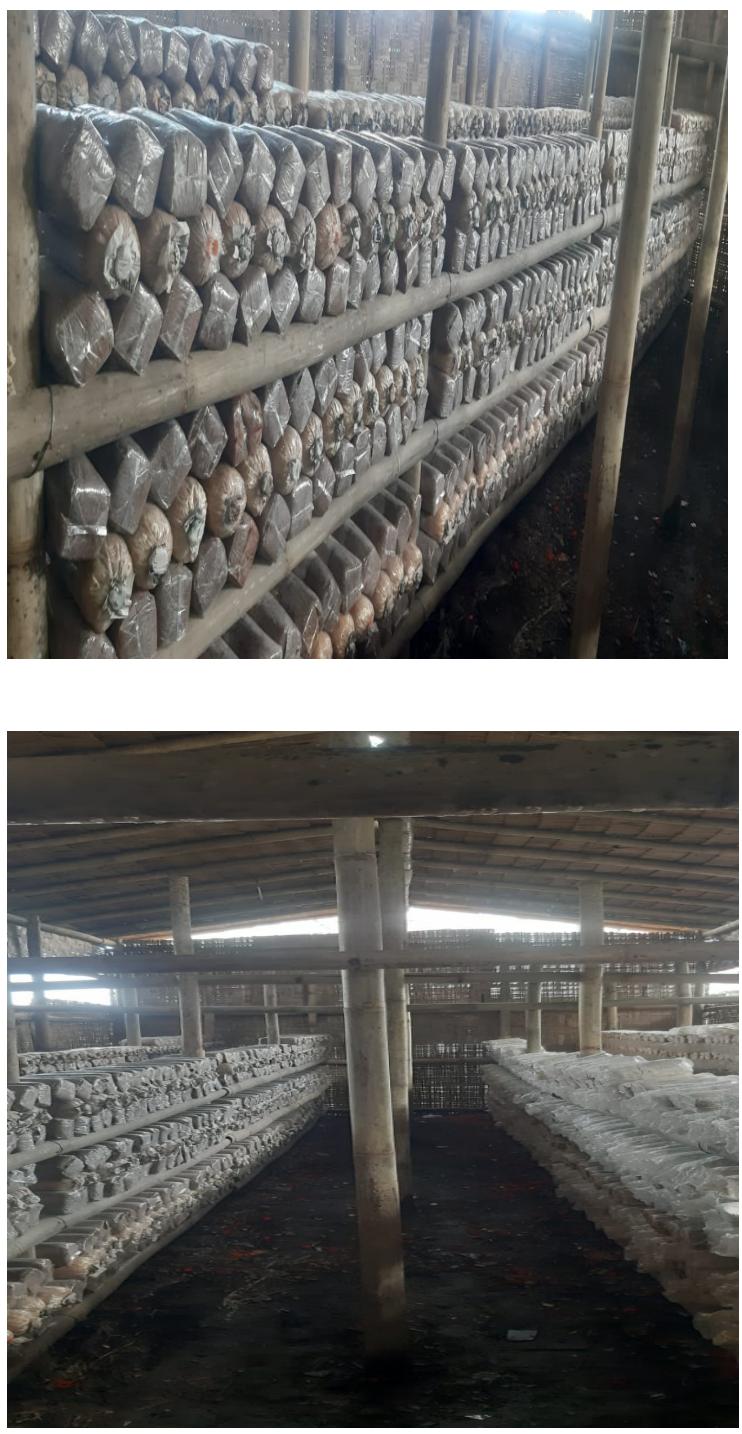

Gambar 2. Baglog jamur

Panen jamur pada satu media tanam dapat dilakukan beberapa kali.
Media tanam jamur dengan ukuran \pm 800 gram dapat panen selama 4-5 kali. Jarak waktu antara panen pertama dan kedua secara umum terjadi antara 7-14 hari. Namun demikian kecepatan pertumbuhan tersebut juga sangat dipengaruhi konisi lingkungan tempat pertumbuhan jamur yang digunakan (Jokrokusumo 2008). Kegiatan pemanenan sangat menentukan kualitas jamur yang dihasilkan. Oleh karena itu dalam pemanenan perlu memperhatikan beberapa hal antara lain penentuan saat panen dan teknik pemanenan itu sendiri.

Pemanenan dilakukan pada saat jamur mencapai pertumbuhan yang optimal, yakni ukurannya cukup besar, tetapi tudungnya belum mekar penuh (ditandai pada bagian pinggir tudung jamur masih terlihat utuh/belum pecahpecah). Ukuran diameter jamur yang siap dipanen rata-rata mencapai 5-10 $\mathrm{cm}$. Pemanenan biayanya dilakukan 3-5 hari setelah calon jamur mulai tumbuh. Waktu pemanenan sebaiknya dilakukan pada pagi hari agar kesegaran jamur dapat dipertahankan, dan untuk mempermudah dalam pemasarannya. Namun demikian pemanenen dapat juga dilakukan pada waktu yang lain sesuai dengan kebutuhan pasar. 
Pemanenan jamur dilakukan dengan teknik/cara mencabut seluruh tanaman jamur yang ada. Pemanenan tidak dapat dilakukan dengan memotong bagian/cabang jamur yang berukuran besar saja, sebab sisa jamur yang ditinggalkan tersebut tidak akan tumbuh menjadi besar, bahkan akan layu/mati. Hal ini disebabkan pada satu tanaman mempunyai stadia tumbuh yang sama. Pencabutan tanaman sampai ke akarnya dimaksudkan untuk menghindari adanya sisa akar atau batang tertinggal, sehingga dapat merusak media (media menjadi busuk) yang dapat berakibat merusak pertumbuhan jamur selanjutnya.

Jamur yang telah dipanen (dicabut), pada bagian akarnya masih banyak menempel kotoran berupa serbuk kayu (media tumbuh), sehingga pada bagian akar tersebut harus dibersihkan dengan memotong bagian tersebut dengan menggunakan pisau yang bersih (lebih baik pisau stainless steel). Dengan cara tersebut, disamping kebersihan jamur lebih terjaga, daya simpan jamur menjadi lebih lama. Pemotongan bagian jamur tidak perlu dipotong pada setiap cabang-cabangnya, sebab apabila hal tersebut dilakukan akan memacu tingkat kerusakan jamur, seperti cepat layu atau cepat busuk. Sisa media tanam jamur tiram mempunyai nilai sebagai pupuk organik, sehingga budidaya jamur tiram ini akan sangat bernilai tinggi untuk menunjang produktifitas kampus ((Purnawanto and Hajoeningtijas 2007).

Kondisi lainnya menunjukkan bahwa, FMIPA sebagai mitra, mendukung penuh kegiatan tersebut dengan menyediakan lahan. Hal ini menunjukkan bahwa kegiatan budidaya jamur tiram di lingkungan kampus merupakan kegiatan positif yang bisa terus dikembangkan sehingga menghasilkan nilai ekonomi yang semakin baik dengan pasar yang menjanjikan dan juga sebagai tempat mahasiswa biologi khususnya untuk peningkatan kualitas pembelajaran dengan mendatangi tempat-tempat budidaya sehingga meningkatkan partisipatif mahasiswa (Ridlo and Alimah 2013)((Wibawa 2016). Terobosan inovasi pada kegitan berikutnya dibutuhkan untuk peningkatan produktivitas industri dan melahirkan perusahaan pemula berbasis teknologi, seperti yang banyak bermunculan di Indonesia saat ini sebagai bentuk menyahuti tantangan industri 4.0 (RISTEKDIKTI 2020). 


\section{KESIMPULAN}

Catatan penting selama kegiatan ini berlangsung adalah respon yang sangat baik dari para mitra agar kiranya dapat dipertimbangkan oleh pihak-pihak terkait. Mitra berharap agar kegiatan sejenis terus berlangsung tiap tahun, sekalipun dalam tema yang berbeda, akan tetapi adanya pertemuan antara mitra dengan berbagai peneliti di bidang pendidikan, pelatihan dan Agrowisata menjadikan kegiatan ini sebagai sarana tukar pikiran untuk kemajuan Agroeduwisata.

Selanjutnya, selain pengembangan pondok jamur, dilakukan juga pendamping terhadap pengurusan ijin sertifikasi halal. Mahasiswa yang melakukan pengembangan jamur ini diberikan materi tentang bagaimana mengurus sertifkat halal dan diikut sertakan dalam pelatihan sistem jaminan halal yang diadakan di LPPOM MUI Sumatera Utara sebagai syarat untuk melakukan setifikasi halal. Dalam pelatihan ini Pondok Jamur Tiram FMIPA Unimed mengahasilkan Manual Sistem Jaminan Halal yang digunakan sebagai panduan dalam menjalankan usaha yang halal.

\section{REFERENSI}

Abdullah, Andika, Soewarto Hardhienata, and Andi Chairunnas. 2012. "Model Pengaturan Suhu Dan Kelembaban Pada Ruang Jamur Tiram Menggunakan Sensor Dht11 DanMikrokontroler.” Journal Article.

Jokrokusumo, Netty Widyastuti dan

Donowati. 2008. "ASPEK LINGKUNGAN SEBAGAI FAKTOR PENENTU KEBERHASILAN BUDIDAYA JAMUR TIRAM (Pleurotus Sp).” J. Tek. Li.

Nasution, Jamilah. 2016. "Kandungan

Karbohidrat Dan Protein Jamur Tiram Putih (Pleurotus Ostreatus) Pada Media Tanam Serbuk Kayu Kemiri (Aleurites Moluccaana) Dan Serbuk Kayu Campuran." Jurnal Eksakta.

Purnawanto, Agus Mulyadi, and Oetami

Dwi Hajoeningtijas. 2007. "Kajian Penggunaan Limbah Media Tanam Jamur Tiram Sebagai Pupuk Organik Alternatif Pada Budidaya Bawang Merah." Agritech.

Ridlo, S, and S Alimah. 2013. "Strategi Pembelajaran Biologi Berbasis Kompetensi Dan Konservasi.” Biosaintifika: Journal of Biology \& 
Biology.

https://doi.org/10.15294/biosaintifi

ka.v5i2.2752.

RISTEKDIKTI. 2020. "Pengembangan Iptek Dan Pendidikan Tinggi Di Era Revolusi Industri 4.0.” RISTEKDIKTI. 2020.

Wibawa, Lutfi. 2016. "Strategi Pemasaran Jamur Tiram.” Staff.Uny.Ac.Id. https://doi.org/10.1007/s11258-

015-0478-4.

Ryan, Yuditian. Budidaya Jamur Tiram Putih Untuk Pemula. Bandung : PT. Pribumi Mekar (halaman 2829).

Suhardjo. R. (1999). Berbagai cara pendidikan gizi. Bumi Aksara.PAU Pangan dan Gizi. Jakarta. 